\title{
To Ascertain the Influence of Bank Officers towards the Factors of Succession Planning
}

\author{
Dr. S. Dhanabagiyam
}

Assistant Professor, Department of Tourism Management, Avinashilingam University, Coimbatore

\begin{abstract}
Succession planning identifies the right potential candidates, for future replacement with the help of the talent pipe line. It is also one of the simple replacements, two or three people who could step into the next higher position on an organizational chart. A talent pool is like combination of internal and external candidates, who are the next aspirants in career development.

For the above discussion of succession planning, the researcher has undergone a survey to understand and develop, an insight on effective succession planning systems especially in banking sector. The researcher view includes the assessment of opinion for the factors of succession planning. Succession planning system in banking sector caters to the future developments by analysing the pitfalls of the present succession planning from the respondents.

A survey research has been done among the Bank officials in Coimbatore district working as both manager and subordinate. Implication of the research has been done among the manager and subordinate in the Coimbatore District. Also, the implication of the research brought out factors like performance and compensation, job satisfaction are not significant.
\end{abstract}

Keywords: Succession planning, Managers, Subordinates, Leadership Skills, Talent Pool, Organization culture.

\section{INTRODUCTION}

There is strong appreciation for succession planning, Because most organization instead of doing simple replacement they can opt a choice of choosing high potential candidate based upon their performance. Hence, it is essential to understand how top management is viewing talent. As previously discussed, managers feel that it is becoming increasingly difficult to attract and retain talented employees.

Demographics are also changing the way in which organizations conceptualize the work force. The baby boomers are large demographic group of individuals born between 1946 and 1964, are becoming eligible for retirement, it is anticipated that the impending baby boomer retirements will reduce the labour force growth, which could result in an insufficient number of employees and or inadequate skills, thus hindering economic progress

Many authors said the discussion for the succession planning process, practices commonly to be used in organizations. It is said in their work that, the succession planning initiative should be tied up with the organizational strategy.

The organizational strategy must drive how the organization approaches managing talent and the succession process. For example, an organization that is strategically attempting to double in size over the next 10 years will need to plan for the accelerated development and back filling of positions as employees move to these newly created positions.

\section{REVIEW OF LITERATURE}

Succession planning is an ongoing process, that focuses on leadership development, not on executive development according to (Caudron ,1996) he advocates maintaining a pool of leaders, which can meet an organization's needs, regardless of what that need might be. Leadership continuity was identified as the most important component of a succession planning process. Good succession planning involves identifying gaps in current and future capabilities, analyzing skills that may be needed in the future, and maximizing and diversifying the pool of executive candidates. Caudron emphasizes that succession planning is not a one-time event, but an ongoing process that should become part of an organization's corporate culture. 
Dr. S. Dhanabagiyam et al. "To Ascertain the Influence of Bank Officers towards The Factors of Succession Planning"

According to (Collins , Porrass ,1997 and Guthridge, Komm, Lawson, 2006) in sum, because high quality managers have more economic impact and are becoming more difficult to find, managing talent is an increasingly high priority for organizations. Many organizations are addressing this challenge through the process of succession planning.

Organizational actions surrounding the transition of an employee through planned leadership positions with the intent of building skills and experiences in preparation for a more advanced position can be done through succession planning according to the view of (Gorne et al.,1998) Historically, succession planning focused on the transitions within family owned businesses later stages succession planning has started to implement by many of the organisation only for the senior management position. Many organisations nearly 40 to $60 \%$ of the organisation have implement succession planning. Recently most of the recent articles trying to make women as the talented person for the leadership pipeline. "Building the leadership pipeline."

Succession planning can also be defined based on the opinion of (Hagberg Consulting Group, 1998) as dynamic, on-going process for systematic identification, assessment and developing leadership talent for future strategic tasks. In executive leadership text, The National Fire Academy defines succession planning as an organized and systematic way to ensure that employees in a particular organization are capable, competent, and willing to replace and succeed to strategic rules within the organization, (NTFA Executive leadership).

"For decades organizations have used succession planning to find their next generation of leaders. Succession planning focused on defining successors for specific jobs. The author (Byham, 1999) makes the case that in today's rapidly changing work environment and such rigid planning is not practical, whereas it may have been when jobs were more static and employees, who typically stayed with the organization for their entire career, moved along defined career paths. uses the phrase "Succession management" to highlight the need for organization to create pools of talented personnel from which it can fill specific leadership position.

In examining the succession planning that Allstate corporation practices (Crockett, 1999), she found that it not only ensures diversity at all levels in the company, but also has helped profits. Allstate contends that diversity in the workplace has nothing to do with political mandates and everything to do with unlocking, the potential of everyone in the organization. They also feel that an organization's people should mirror that they serve. Because all employee's career counseling results in the development of their opportunities. Allstate's employees spend in excess of 540,000 hours annually in a classroom setting. Allstate has been ranked by fortune magazine as one of the 50 best companies for Asians, Blacks, and Hispanics, 40 percent of the executives at Allstate are women and 21 percent are minorities, due in large part to an ongoing commitment of leadership development that starts upon employment.

There is a series by writing about the importance of mastering supervisory skills at each level before advancing (Toth,1999) feels there are three skills that need to be mastered technical, human, and conceptual. Technical skills are learnt early in a person's career. Then, as the person moves up, human and conceptual skills, become more important.

The author identifies the reduction of talented employees, in order to fully appreciate why succession planning has become such a substantial priority for organizations, it is essential to understand how the top management is viewing talent. (Axelrod et al., 2000) previously discussed, managers feel that it is becoming increasingly difficult to attract and retain talented employees the importance of qualified managers is magnified. In a survey of 410 executives at companies in the United States, the best of 20 percentage managers were estimated to increase productivity by 40 percentage, increase profit by 48 percentage, and increase sales revenue by 67 percentage. Demographics are also changing the way in which organizations conceptualize the work force. The baby boomers, a large demographic group of individuals born between 1946 and 1964, are becoming eligible for retirement.

Succession planning has been a part of the business, leadership worlds, for as long there have been the worlds of business and leadership. It just went by another name, grooming. The author provides a prototypical view of what succession planning has looked like, and probably still looks like, in many organizations. First, organizational leaders identified a younger member of the organization as having the right stuff. The chosen one would be ready to assume their position in their hierarchy of the organization. The mentor would be trusted member of the organization who not only knew the technical aspects of the job, but also well versed in the informal aspects of the organization (Beeson, 2000). 
Dr. S. Dhanabagiyam et al. "To Ascertain the Influence of Bank Officers towards The Factors of Succession Planning"

The establishment of an acceleration pool for nominated participants is a feature of some succession management schemes. (Byham et al., 2000) explains in an acceleration pool system, high potential candidates are identified and given training, coaching, and a wide range of professional experience within the organisation. This identification and development of a pool of high potential employees marks another distinct change from earlier succession planning approaches. Large organizations might have more than one acceleration pool that could include a pool for supervisory level participants, one at middle management, and one for senior levels. Each pool, which might encompass one or two organizational levels, would prepare people for the next major step in the organisation. The size of a pool will depend on the number of positions it is expected to supply and the selection ratio that the organisation would like to have in filling target positions. The number of acceleration pools reflects how an organisation is structured, as well as how it thinks about its high potential and talented employees. Organizations may incorporate formal mentoring or coaching programmes for employees into acceleration pools.

Succession planning is not just for family business but also for the continuing success of all endeavours. It is one of the most critical components of an organization's strategy as continued success is the ability, which continuously provides new leaders for the organization, succession planning is an organized and systematic way to ensure that employees in a particular organization are capable, competent, and willing to replace and/or succeed to strategic roles within the organization (Fema,2000).

(Nyce and Schieber, 2001) they mentioned in many disciplines, researchers have struggled to understand the conditions that facilitate individuals fully engaging their will when taking certain actions. In the context of work, this evolved to how do organizations fully engage their employees so that they can contribute their maximum value. In the shift from the industrial age to the knowledge age, organizations have struggled more with how to fully engage employees in their work.

The effective organizations do not passively wait for the future, they create it by investing their time, thoughts, and planning in order to ensure the continuity of their leadership talent. This process is otherwise known as succession planning. "Succession planning is a process by which an organization ensures the continuity of its leadership into the future. It is a critical aspect of business strategy that requires an organization's best thinking" (Goudy, 2002).

The U.S. government, now face a leadership crisis: In the Next 10 years, a large number of employees in upper and middle management positions, mostly Baby Boomers, will retire. According to the impending crisis, too many jobs and only few people are available. Unfortunately, planning for succession is often neglected or takes place when it is too late after key people has left the organization and there are no internal candidates to fill the leadership positions. As a result, organizations may find themselves in the midst of a crisis without clear leadership for the future (Herman,2002). Also, (Rothwell and Friedman, 2002) explained the organizational strategy, which must drive the organizational approaches, managing talent and the succession process. For example, an organization that is strategically attempting to double in size over the next 10 years will have to plan for the accelerated development and back filling of positions as employees move to these newly created positions. In contrast, an organization more intent on maintaining its position in the market place, will have to plan for succession from the standpoint of normal attrition and retirements of key position holders. As with many organizational initiatives, senior leadership support is crucial.

(Taylor and McGraw,2004) they explained the current usage of succession management programs in Australian-based organizations, and gain information on the characteristics and perceived effectiveness of such programs, a national research study was undertaken. A total of 711 human resource management professionals from a range of organizations across the country answered the questionnaire; the response rate was 59 percent. Succession planning programs were present in less than half of the respondent's organizations. Furthermore, these programs were generally less than five years old. The prime imperatives for introducing succession management programs were reported as the desire to improve business results, and the need for new skill requirements in the business.

The succession planning practice, is practiced more systematically in a large number of organizations at levels beyond just senior management. In fact, estimates suggest that 40 percentage to 65 percentage of companies have implemented a succession planning process. As a caveat, it should be noted that the samples for the Garman and Glawe research were from previous studies that had limited scope in terms of diversity of businesses (Garman and Glawe ,2004) 
Dr. S. Dhanabagiyam et al. "To Ascertain the Influence of Bank Officers towards The Factors of Succession Planning"

The business literature regarding how to build a strategic workforce, where the succession planning has often emerged as the answer. In fact, to some succession planning is the only answer. In the bestseller Built to Last, the authors refer to a culture of succession planning not only as a habit of visionary companies, but also as the unifying factor (Ciampa et al.,2005).

The focus of CEO on succession planning in recent articles according to (Hewlett and Luce , 2005) ,which have a focus on CEO succession planning. Keeping talented women on the path for future leadership positions refer to as "building the leadership pipeline."

The six nurse executives from five settings were interviewed to learn more about how succession planning is being applied in today's practice. Their experiences, presented in this article by (Beyers and Marjorie, 2006) provide a snapshot that succession planning can be applied in different organizations. Interviews share their personal philosophy, concepts, and approaches to succession planning. Although these nurse executives approach succession planning differently, they share a belief that succession planning is embedded in the nurse executive role and that succession planning is the key to sustaining quality nursing practice.

(Fulmer et al., 2009) they discussed the current stressful recessionary period, the need for highly effective managers who can skillfully direct the company strategic initiatives such as disruptive innovation, restructuring, strategic renewal and mergers greatly increases. It is more important than ever to study the succession planning and leadership training of best-practice firms to learn better ways to develop high potential leaders. This paper aims to investigate this issue that employees with high leadership potential need to be systematically identified and tracked by line managers as part of an overall strategic succession planning process. Success in developing the next generation of leaders requires creating a talent management system in which selection, development, performance management, succession and career management are aligned, reviewed and supported by senior management. Some of the more cost and resource efficient practices for implementing a successful early stage high potential program includes; a special learning and development track for the high potentials; rotation of managers across disciplines, divisions, geographies, technology based learning, action learning, and coaching mentoring (internal and external) programs. To ensure that the talent pool supports the company's overall strategy, the abilities of the high potential individuals should be shaped to correspond with the emerging leadership needs of the next decade. The "best firms for leaders" are typically twice as likely to use a variety of developmental techniques for their "best and brightest."

\section{OBJECTIVES OF THE STUDY}

1) To Analyze the influence of opinion of bank managers and subordinates towards the factors of Succession planning

\section{RESEARCH METHODOLOGY}

\section{Sampling Method}

The study is descriptive in nature, with the sampling method of multistage stratified random sampling. The population size of the Bank officers, working in manager and subordinate cadre in Coimbatore is 6150 ,

Since, the population size is known, the sample size is derived, and it is 584 , taken for the study may be sufficient to meet out the objectives of the same.

\section{Analysis for Data Collected}

For the above discussion data has been collected from the samples among bank officials, finally Analysis has been carried:

The following statistical tools where used for analysis namely:

1) ' $Z$ ' test

Z-test is based on the normal probability distribution and is used for judging the significance of several statistical measures, particularly the mean. The relevant test statistics is worked out and compared with its probable value at a specified level of significance for judging the significance of the measure concerned. This test is used when binomial distribution or frequently used test in research studies. This test is used 
Dr. S. Dhanabagiyam et al. "To Ascertain the Influence of Bank Officers towards The Factors of Succession Planning"

even when binomial distribution or t-distribution is applicable on the presumption that such a distribution tends to approximate normal distribution as ' $n$ ' becomes larger. Z-test is generally used for comparing the sample proportion to a theoretical value of population proportion or for judging the difference in proportions of two independent samples when $\mathrm{n}$ happens to be large. Besides, the test may be used for judging the significance of median, mode, coefficient of correlation and several other measures.

\section{ANALYSIS OF DATA}

\section{Analysis of Opinion of Managers and Subordinates on Factors of Succession Planning}

To analyse whether there is any significant difference between the opinion of managers and subordinates on factors of succession planning.

Ho: There is no significant difference between managers and subordinates on factors of succession planning.

Table5.1. Analysis of opinion of managers and subordinates on factors of succession planning

\begin{tabular}{|c|c|c|c|c|c|c|}
\hline $\begin{array}{l}\text { Factors of succession } \\
\text { planning }\end{array}$ & Cadre & mean & S.D & Zo & $\begin{array}{l}\text { Level of } \\
\text { significance }\end{array}$ & $\begin{array}{l}\text { Remarks on } \\
\text { Null hypothesis }\end{array}$ \\
\hline Job satisfaction & $\begin{array}{l}\text { Manager } \\
\text { Subordinate }\end{array}$ & $\begin{array}{l}28.96 \\
27.94\end{array}$ & $\begin{array}{l}4.14 \\
4.25 \\
\end{array}$ & $\begin{array}{l}2.87 \\
2.87\end{array}$ & 0.04 & Rejected* \\
\hline $\begin{array}{l}\text { Performance satisfaction as } \\
\text { perceived by the employees }\end{array}$ & $\begin{array}{l}\text { Manager } \\
\text { Subordinate }\end{array}$ & $\begin{array}{l}18.99 \\
18.96\end{array}$ & $\begin{array}{l}2.99 \\
2.63\end{array}$ & $\begin{array}{l}0.13 \\
0.13\end{array}$ & 0.89 & Accepted \\
\hline Work requirements & $\begin{array}{l}\text { Manager } \\
\text { Subordinate }\end{array}$ & $\begin{array}{l}18.55 \\
18.47\end{array}$ & $\begin{array}{l}2.62 \\
2.51\end{array}$ & $\begin{array}{l}0.40 \\
0.39\end{array}$ & 0.68 & Accepted \\
\hline $\begin{array}{l}\text { Performance } \\
\text { compensation }\end{array}$ & $\begin{array}{l}\text { Manager } \\
\text { Subordinate }\end{array}$ & $\begin{array}{l}26.32 \\
26.95\end{array}$ & $\begin{array}{l}3.78 \\
3.29\end{array}$ & $\begin{array}{l}2.06 \\
2.04\end{array}$ & 0.03 & Rejected* \\
\hline
\end{tabular}

Note: *Significant difference at $5 \%$ level

Table: 5.1 indicate the factors of job satisfaction, performance and compensation among managers and subordinates are significantly different, the null hypothesis is rejected.

It is vice-versa in case of factors performance satisfaction as perceived by the employees and work requirements among managers and subordinates, their opinion do not vary, so, the null hypothesis is accepted.

\section{FINDINGS AND SUGGESTION}

The researcher found the opinion of manager and subordinates for factors of job satisfaction, performance and compensation is not significant

The response of managers and subordinates respondents on factors including job satisfaction, performance and compensation differs. This result indicates that opinion of manager and subordinates vary from each other. Thus, there may be suitable up gradation that can be made in succession planning to suit the requirement of respondents.

Banks must ensure job satisfaction according to their cadre, which would enable banks to retain their skilled employees, and hence satisfaction should be enhanced without gender-biasedness. (A.K. Purwar 2004)

Organizational culture has to be focused on the basis of increasing employee productivity, mapping and developing competency, identifying talent and proper grooming; transforming staff from being "Transaction processors" to business professionals; developing strong business orientation among employees through sales culture and customer centric approach.

\section{CONCLUSION}

The main objective behind the research was to examine the opinion of manager and subordinate for the factors of succession planning among bank officials of Coimbatore District. This small research towards the factors of succession planning identifies the current pitfalls in the organization culture. This suggestion if made positive, which could improve the talent replacement for the employees who prefer to leave the organisation, with necessary talent and experience, by filling these positions.

The study highlighted the following: 
Dr. S. Dhanabagiyam et al. "To Ascertain the Influence of Bank Officers towards The Factors of Succession Planning"

Banks may also have to consider succession planning, direct induction/ recruitment at senior levels from unconventional talent pools. Spot the right talent and provide them with a challenging work environment that the banking sector can certainly provide.

\section{REFERENCES}

[1] Axelrod E.L., Handfield-Jones H. and Welsh T.A. (2000), 'War for talent, part two',Journal of McKinsey Quarterly, Vol.2, pp.9-12.

[2] Besson J. (2000), 'Succession planning', Across the Board, Vol. 37, pp.38-42.

[3] Byham W.C. (2000), 'Grooming new millennium leaders', HR Magazine, Vol.44, pp.46-51.

[4] Caudron S. (1996), 'Plan today for an unexpected tomorrow', Personnel journal, Sep, pp. 4045.

[5] Ciampa D. (2005), 'Almost ready: How leaders move up', Harvard Business Review, Vol.83, pp. 46-53.

[6] Collins, J.C. and Porras, J.I. (1997), 'Built to last: Successful habits of visionary companies', New York: Harper Collins.

[7] Crockett. (1999), 'Diversity Winning competitive advantage through a diverse workforce', HR focus, pp. 9-10.

[8] Federal Emergency Management Agency. (2000), 'Executive Leadership', Student manual Emmitsburg, MD: Author.

[9] Garman A.N. and Glawe J. (2004), 'Succession planning. Consulting Psychology Journal: Practice and Research', Vol.56, pp.119-128

[10] Gorne A. (1998), 'Good advice can make a success of succession', BRW, Vol.20, pp.82-84.

[11] Goudy K. (2002), 'Passing the torch. Spotlight (Institute for Real Estate Management)', Vol 6, No.5, pp. 24-28.

[12] Hagberg R. (1998), Hagberg Consulting Group (online), Available:http:/www. successionplanning.com/key-lessons.html (2/26/01).

[13] Herman R. (2002), 'The impending crisis, too many jobs, Too few people', Winchester, VA: Oakhill Pres.

[14] Nyce S. and Shieber S. (2001), 'The decade of the employee: The workforce environment in the coming decade', Benefits Quarterly, (first quarter), pp. 60-79.

[15] Purwa A.K. (2004), 'Harnessing Facilitators', Indian Banking- managing transformation, ICFAI University press, Hyderabad, Vol.1, pp 61-68.

[16] Rothwell W.J. (1994), 'Effective Succession planning: Ensuring leadership Continuity and Building Talent from Within', New York, NY: AMACOM.

[17] Tracy Taylor. and Peter McGraw. (2004), 'Succession management practices in Australian organization', International Journal of Manpower, Emerald Publishers, Vol. 25, No. 8, pp.741 758.

\section{AUTHOR'S BIOGRAPHY}

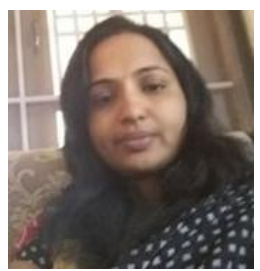

Dr S.Dhanabagiyam Currently working as Assistant Professor in Department of Tourism Management, Avinashilingam Institute for Home Science and Higher Education for Women, Coimbatore. She completed her doctorate at Bharathiar School of Management and Entrepreneur Development, Bharathiar University. Her Qualification include B.Sc., MBA (HR)., MBA(Tourism and Hotel Management)., $\mathrm{Ph} . \mathrm{D}$. She also got good Academic and Industry Experience. Her area of Interest are Performance Management System, Talent Management, Succession planning. Also she is interested in Tourism and Hospitality Management Sector. 